\title{
THE IDENTIFICATION OF SALMONELLA INFECTION IN HATCHING EGGS AND PRODUCTS OF TURKEY-KEEPING
}

ОСОБЕННОСТИ АРИЗОНОЗА ИНДЕЕК. ИДЕНТИФИКАЦИЯ САЛЬМОНЕЛЛАИНФЕКЦИИ В ИНКУБАЦИОННОМ ЯЙЦЕ И ПРОДУКТАХ ИНДЕЙКОВОДСТВА

Пименов Н.В., доктор биологических наук

Pimenov N.V., Doctor of Biological Sciences

Лаишевцев А.И., Пименова В.В., научные сотрудники

Laishevtcev A.I., Pimenova V.V., Researchers

\section{ФГБОУ ВО «Московская государственная академия ветеринарной медицины и \\ биотехнологии - МВА имени К.И.Скрябина», Москва, Россия}

Federal State Budgetary Educational Institution of Higher Education «Moscow State Academy of Veterinary Medicine and Biotechnology - MVA named after K.I. Skryabin», Moscow, Russia

\begin{abstract}
АННОТАЦИЯ
Экспериментально проведено инфицирование индеек музейным штаммом возбудителя аризоноза. Уточнены клинические признаки заболевания, патологоанатомические изменения. Установлен спектр антибиотиков, позволяющий устранить аризоноз. Выявлены культуральные, биохимические особенности возбудителя, отсутствие его вирулентности для белых мышей. Установленные свойства позволяют усовершенствовать методы идентификации Salmonella Arizonae и диагностику аризона-инфекции.
\end{abstract}

\section{ABSTRACT}

Experimentally infected turkeys conducted museum strains of arizonoza. Refined clinical signs of the disease, pathological changes. Established spectrum antibiotic that eliminates arizonoz. Revealed cultural, biochemical characteristics of the pathogen, its absence of virulence for white mice. The properties allow to improve the methods of identification and diagnosis of Salmonella Arizonae Arizona infection.

\section{КЛЮЧЕВЫЕ СЛОВА}

Сальмонеллёз индеек; Salmonella Arizonae; Аризоноз; Идентификация; Антибиотикорезистентность; Экспериментальное инфицирование.

\section{KEY WORDS}

Salmonellosis of turkeys; Salmonella Arizonae; Arizonosis turkey; Antibiotic resistance; Clinical features; Pathological changes; Experimental infection.

Относительно новая в нашей стране отрасль промышленного птицеводства индейководство динамично развивается. Так, в 2014 году рост производства мяса индейки составил 25 \% по сравнению с 2013 годом. Появляются новые предприятия по откорму индюшек, отечественные инкубаторы. Тем не менее, репродукция индейки в промышленных масштабах в нашей стране еще недостаточно развита, поэтому предприятия данной отрасли остаются зависимыми от импортируемого в страну инкубационного яйца ${ }^{1}$. Сальмонеллез, вызванный бактерией рода Salmonella подвида Arizonae, - аризоноз представляет серьезную проблему в индейководстве.

Индюшки являются наиболее восприимчивыми видами птиц к данному возбудителю. Болезнь протекает наиболее остро у индюшат в первую неделю жизни, реже у 3-недельных и проявляется диареей, искривлением шеи, судорогами, иногда слепотой. Индюшата нахохливаются, становятся вялыми, у них отмечаются серозногнойные выделения из глаз. Отход достигает 50 \%.

Сальмонелла-инфекция подвида Arizonae причиняет огромный экономический ущерб в ряде стран с хорошо развитым индейководством - США, Канаде, ФРГ ${ }^{2}$. В соответствии с директивами совета 2009/158/EC по ветеринарно-санитарным 
условиям, регламентирующим торговлю внутри Сообщества и импорт из третьих стран домашней птицы и инкубационных яиц, инкубационное яйцо индейки в обязательном порядке проходит контроль на наличие возбудителя сальмонеллеза подвида Arizonae ${ }^{3}$. По условиям Таможенного союза и ЕАЭС (глава 14 Единые ветеринарные (ветеринарно-санитарные) требования, предъявляемые к товарам, подлежащим ветеринарному контролю (надзору) инкубационные яйца и индюшата допускаются к ввозу с территории свободной от сальмонеллеза в соответствии с рекомендацией кодекса МЭБ. Продукция, обсемененная сальмонеллой, к ввозу не допускается ${ }^{4}$.

Вспышки сальмонелла-инфекции, вызванные продуктами птицеводства в последние годы являются достаточно частым явлением. При современных тенденциях развития индейководства на территории Российской Федерации необходимо обратить внимание на продукцию данной отрасли, импортируемую в страну. Так в США зараженными являются 60 \% кур и 23 \% индеек ${ }^{5}$. В частности, в США в 2011 году распространялась инфекция Salmonella Heidelberg, охватившая более 150 человек в 34 штатах, вызванная, как показали лабораторные анализы, зараженным фаршем из мяса индейки. В ноябре 2011 года поступили сообщения о 179 случаях заболевания, вызванных этим же сероваром сальмонеллы, но уже из-за продуктов, изготовленных из печени кошерных цыплят. Многие случаи были тяжелыми и требовали госпитализации ${ }^{6,7,8}$.

Пищевые инфекции наносят, кроме того, огромный экономический ущерб птицеперерабатывающей промышленности, связанный с отзывом продуктов из торговой сети. Только в США в 2007-2009 гг. имели место 44 случая отзыва продуктов 9. Так, компания Cargill в августе 2011 года отозвала 36 млн. фунтов фрарша из мяса индейки и продуктов из него из-за вероятного заражения сальмонеллой, а в сентябре еще 185 тыс. фунтов по этой же причине ${ }^{10,11}$.

Как свидетельствуют результаты обследования специалистами ВОЗ безопасности цыплят в России, почти половина этих тушек содержит сальмонеллу ${ }^{12}$. Несмотря на принимаемые во всех секторах птицепрома меры, от сальмонеллы, по мнению ученых, нельзя избавиться полностью: ни одно из нововведений не гарантирует полного ее отсутствия в тушке птицы. Но сальмонеллезную обсемененность сырой убойной птицы можно и необходимо снижать до безопасного для человека уровня ${ }^{13}$.

Большого внимания требует сальмонеллезное инфицирование яиц. В середине 2010 года в США из торговли была отозвана огромная (полумиллиардная) партия яиц, поступивших от компании Wright County, из-за их заражения сальмонеллой, которое вызвало в ряде штатов вспышку заболевания людей сальмонеллезом. Сейчас в США в целях профилактики запрещено отправлять яйца на реализацию до получения результатов тестирования на сальмонеллу 14, 15. Применение строгих мер биологической безопасности на яичных фермах, использование пребиотиков и пробиотиков в кормах, а также вакцинация несушек против сальмонеллеза способствуют оздоровлению стад несушек и устранению угрозы попадания к потребителю зараженных яиц ${ }^{16}$. Заражение внутреннего содержимого яиц на стадии их образования происходит редко, обычно инфекция проникает внутрь яйца с загрязненной скорлупы, если яйца неправильно или слишком долго хранятся ${ }^{17,} 18$.

Загрязнение яичной скорлупы, в частности, видимое фекальное загрязнение является наиболее частым источником возбудителя сальмонелла-инфекции, проникающего внутрь яйца. Ситуация усугубляется тем, что в Евросоюзе запрещена мойка яиц, в то время как она в значительной мере снижает вероятность заражения внутреннего содержимого яиц без значительного повреждения скорлупы или ее кутикулы ${ }^{19}$. При мойке яиц не только устраняется их видимое загрязнение, что заметно улучшает товарный вид, но и осуществляется санитарная обработка. Исследователями Техасского Университета (США) разработана технология санитарной обработки яиц ультрафиолетовым облучением с предварительным опрыскиванием перекисью водорода ${ }^{20}$. 
Различные серовары бактерий рода сальмонелл имеют широкое распространение в птицеводстве, но для индейководства наибольшей проблемой является серовар Arizonae.

Из вышесказанного видно, что выявление сальмонелла-инфекции в инкубационном яйце и продуктах индейководства представляет актуальную задачу. Особенности культуральных, биохимических и патогенных свойств бактерий подвида Arizonae требуют совершенствования методов их идентификации при выявлении в поднадзорных продуктах индейководства.

Целью настоящей работы явилось изучение сальмонелла аризона-инфекции при экспериментальном инфицировании и особенностей бактериологической диагностики, присущей данному серовару сальмонелл.

Материалы и методы. В работе использованы музейные штаммы бактерий, питательные среды, реактивы, лабораторная посуда и оборудование, животные: белые мыши массой 16-18 г и индейки разной массы. В ходе работы применяли эпизоотологические, бактериологические, серологические, статистические методы исследований.

\section{РЕЗУЛЬТАТЫ ИССЛЕДОВАНИЙ}

Для изучения и характеристики пока редко встречающегося зооноза в нашей стране - аризоноза в лабораторных условиях была смодулирована болезнь методом экспериментального инфицирования индеек в разном возрасте и лабораторных животных - белых мышей.

Для достижения поставленной цели использовали два штамма Salmonella Arizonae, полученных из коллекции музейных штаммов Россельхознадзора: S. Arizonae S0-50, S. Arizonae S05. Для определения вирулентных свойств данных штаммов белым мышам массой 16-18 г подкожно вводили взвесь свежей культуры возбудителя в различных концентрациях. Объем инокулята составлял $1 \mathrm{~cm}^{3}$. На каждое разведение исследованных штаммов использовали по 5 белых мышей. Исходную концентрацию определяли, используя оптический стандарт мутности для энтеробактерий.

Животных содержали по принципу аналогов. Наблюдение вели в течение 14 дней. Фиксировали наличие или отсутствие заболеваемости и гибели мышей. Полученные данные представлены в таблице 1.

Таблица 1 - Результаты исследований по вирулентности штаммов Salmonella Arizonae на белых мышах

\begin{tabular}{|c|c|c|c|}
\hline $\begin{array}{c}\text { Инфицирующий } \\
\text { штамм }\end{array}$ & $\begin{array}{c}\text { Группа } \\
\text { животных }\end{array}$ & $\begin{array}{c}\text { Концентрация } \\
\text { возбудителя }\end{array}$ & $\begin{array}{c}\text { Количество погибших } \\
\text { животных }\end{array}$ \\
\hline \multirow{4}{*}{ S. Arizonae S0-50 } & Группа 1 & $10^{3}$ & 0 из 5 \\
\cline { 2 - 4 } & Группа 2 & $10^{4}$ & 0 из 5 \\
\cline { 2 - 4 } & Группа 3 & $10^{5}$ & 0 из 5 \\
\cline { 2 - 4 } & Группа 4 & $10^{6}$ & 0 из 5 \\
\cline { 2 - 4 } & Группа 5 & $10^{7}$ & 0 из 5 \\
\hline \multirow{5}{*}{ S. Arizonae S05 } & Группа 6 & $10^{3}$ & 0 из 5 \\
\cline { 2 - 4 } & Группа 7 & $10^{4}$ & 0 из 5 \\
\cline { 2 - 4 } & Группа 8 & $10^{5}$ & 0 из 5 \\
\cline { 2 - 4 } & Группа 9 & $10^{6}$ & 0 из 5 \\
\cline { 2 - 4 } & Группа 10 & $10^{7}$ & 0 из 5 \\
\hline
\end{tabular}

Как видно из результатов таблицы 1, по истечении периода наблюдения, все животные оставались живы. Признаков заболеваемости у мышей не отмечали. По истечении 14-дневного периода животные были убиты для проведения бактериологического контроля. Отбор проб проводили от животных всех групп в 
полном объеме численности. Проведение бактериологического исследования осуществляли в соответствии с «МУ 4.2.2723-10 Лабораторная диагностика сальмонеллезов, обнаружение сальмонелл в пищевых продуктах и объектах окружающей среды» ${ }^{21}$. Для исследования были отобраны печень, селезенка и кишечник с содержимым.

Высевы на простые, диффференциально-диагностические и селективные питательные среды позволили выделить изоляты микроорганизмов из патологического материала от всех животных, использованных в опыте. Биохимическую идентификацию микроорганизмов проводили при помощи тест системы Microbact12E, результаты которой подтвердили, что данные изоляты относятся к роду Salmonella подвиду Arizonae. T.e. согласно полученным данным, можно утверждать, что штаммы сальмонелла аризона не патогенны для белых мышей - при общем ассимилировании в структуры организма не вызывают у лабораторных объектов белых мышей проявление болезни и гибель.

В процессе проведения бактериологических исследований был отмечен ряд особенностей сальмонелл аризона, отличающих их от других представителей рода. Так, при использовании тест-системы Microbact12E фермент ortho-Nitrophenyl- $\beta$ galactoside (ONPG) даёт положительный результат, что в свою очередь указывает на возможность штаммов данного подвида сальмонелл сбраживать лактозу. На питательном агаре Эндо оба исследуемых штамма имели металлический блеск у колоний, свойственный для Escherichia Coli, что в свою очередь говорит о том, что обе культуры являются лактозоположительными. Это свойство отличает возбудителя от сальмонелл других видов и подвидов рода Salmonella, наиболее распространенных возбудителей сальмонеллеза птиц.

Следующей отличительной чертой, которую мы отмечали при культивировании культуры, стала положительная бета-глюкуронидазная активность штамма S. Arizonae S0-50, наблюдаемая на питательной среде OXOID CM1007. При культивировании в течение 24 часов при температурном режиме $37{ }^{\circ} \mathrm{C}$ культура сальмонеллы данного штамма приобрела синий цвет, в то время как штамм S. Arizonae S05 имел пурпурную окраску. Изоляты и штаммы бактерий рода Salmonella подвида Arizonae имеют нетипичный для остальных подвидов данного рода биохимический профиль. Наиболее наглядно это можно увидеть на диффреренциальных средах для энтеробактерий. Так, как уже было отмечено, на среде Эндо они имеют металлический блеск, что обусловлено возможностью сбраживать лактозу. Помимо сероваров Arizonae данной возможностью обладают серовары подвида Diarizonae. Положительная бета-глюкуронидазная активность сероваров свойственна многим штаммам подвидов Arizonae и Diarizonae - синий цвет колоний на специальной питательной среде является для них более характерным. Также для сальмонелл подвидов Arizonae, Diarizonae вида S. enteric и, кроме них, вида S. bongori свойственна положительная бета-галактозидазная активность. Данные качества не характерны для сальмонелл других серовариантов вида S. enterica, в т.ч. основных этиопатогенных вариантов для птиц - Ss. enteritidis, typhimurium, pullorum, gallinarum, kentucky, infantis, anatum. Для выявления бета-галактозидазной активности возможно использование тест-системы ЭНТЕРО тест $24 \mathrm{H}$.

Кроме того, с использованием данной тест-системы возможно выявление свойства утилизации культурой малоната натрия. Положительная реакция малонатного теста проявляется у сероваров подвидов Arizonae, Diarizonae и Salamae.

Гидролиз желатина свойственен для Arizonae, Diarizonae, Salamae и Houtenae. Данное свойство не характерно другим сальмонеллам, в т.ч. основным этиопатогенам для птиц.

Дальнейшим этапом нашего исследования стало изучение экспериментальной инфекции аризоноза для индеек и определение вирулентных свойств штаммов S. Arizonae S0-50 и S. Arizonae S05 для птиц, в частности индейки различных возрастных категорий. Для опыта использовали по 3 птицы на каждый штамм в возрасте 28, 42 и 240 дней. Заражение проводили подкожно в дозе 1 мл 
бактериальной суспензии суточной агаровой культуры с возрастающей концентрацией по отношению к возрасту птицы. Наблюдение за птицей вели в течение 30 дней. Характеризовали наличие признаков болезни, ее течение, фриксировали гибель птиц и патологоанатомические данные, a также результаты бактериологического исследования патологического материала от трупов павшей птицы и убитой для контроля выжившей птицы по окончании периода наблюдения. Результаты исследований вирулентности штаммов Salmonella Arizonae на индейках представлены в таблице 2.

Таблица 2 - Результаты исследований вирулентности штаммов Salmonella Arizonae на индейках

\begin{tabular}{|c|c|c|c|}
\hline $\begin{array}{c}\text { Инфици- } \\
\text { рующий } \\
\text { штамм }\end{array}$ & Номер птицы & $\begin{array}{c}\text { Концентрация } \\
\text { возбудителя }\end{array}$ & Гибель птицы \\
\hline \multirow{2}{*}{$\begin{array}{c}\text { S. Arizonae } \\
\text { S0-50 }\end{array}$} & № 1 (возраст 28 дней) & $10^{6}$ & Гибель индейки на 8 сутки \\
\cline { 2 - 4 } & № 2 (возраст 42 дней) & $10^{\prime}$ & Птица не пала \\
\cline { 2 - 4 } & № 3 (возраст 240 дней) & $10^{8}$ & Птица не пала \\
\hline \multirow{2}{*}{$\begin{array}{c}\text { S. Arizonae } \\
\text { S05 }\end{array}$} & № 4 (возраст 28 дней) & $10^{6}$ & Гибель индейки на 6 сутки \\
\cline { 2 - 4 } & № 5 (возраст 42 дней) & $10^{\prime}$ & Птица не пала \\
\cline { 2 - 4 } & № 6 (возраст 240 дней) & $10^{8}$ & Птица не пала \\
\hline
\end{tabular}

Bсе птицы во время эксперимента находились в раздельных клетках, не имеющих общих кормушек, поилок и иных средств переноса возбудителя. Кормление осуществляли комбикормом для индюшат от 0 до 6 недельного возраста ПК ВМ Т8501 Best Mix.

У индеек под номерами 1 и 4 в первые трое суток после инфицирования клинических признаков заболевания не наблюдали. На 3 сутки у птицы № 4 и на 4 сутки у птицы № 1 отмечали признаки угнетения, малоподвижность, сонливость, полидипсию, снижение аппетита, дрожь. В дальнейшем клиническая картина характеризовалась развитием учащения дыхательных движений и одышкой. Кроме того появлялась диарея - при этом фрекальные массы становились жидкой консистенции желто-коричневого цвета с зеленоватым оттенком, также наблюдали прилипание фекальных масс к анальному отверстию. У птицы под номером 1 на 5 сутки при тех же клинических признаках в фрекальных массах появились прожилки крови. Во время последующего наблюдения у обеих птиц фриксировали полное отсутствие аппетита и нарушение координации движений, взъерошенность оперения. Данные индейки перестали перемещаться по клетке, прижавшись к стенке. У них в этот период отмечали опистотонус с запрокидыванием головы.

Гибель птицы под номером 4 произошла на 6 сутки, гибель птицы под номером 1 произошла на 8 сутки.

У птиц под номерами 2, 3, 5, 6 проявились следующие клинические признаки: снижение аппетита, вялость, малоподвижность, диарея (фекалии приобрели зеленоватый оттенок и жидкую консистенцию). Проявление данных признаков отмечали на 3-4 сутки после экспериментального инфицирования, на 8-9 день признаки сглаживались, фекалии приобретали оформленность, птица активнее начинала потреблять корм. Данные индейки, не смотря на повышенную концентрацию возбудителя, в сравнении с месячными индейками не погибли в течение 30-дневного периода наблюдения.

При вскрытии павшего месячного молодняка индеек под номерами 1 и 4 у обоих индюшат фриксировали следующие патоморфологические изменения: печень находилась в увеличенном состоянии - при надрезе Глиссоновой капсулы паренхима печени выпирала и приобретала сферическую форму. В толще паренхиматозной ткани печени отмечали светло-серые очажки некроза. Кроме того, стоит отметить фрибринозно-гнойное воспаление самой капсулы печени. В брюшной полости имелось незначительное скопление гнойного экссудата. При этом сама печень имела неравномерно коричнево-серый цвет. 
В просвете тонкой кишки отмечали скопления слизистой массы с газами. Толстый отдел кишечника имел петехии без признаков эрозии. Селезенка в состоянии мегалии. При разрезе селезенки устанавливали повышенное кровенаполнение пульпы. Сердечная мышца при вскрытии имела некротические узелки, при этом цвет самого сердца приобретает сероватый оттенок. У птицы № 4 при вскрытии черепной коробки отмечали значительное воспаление оболочки головного мозга.

Взрослая птица под номерами 2, 3, 5, 6 была подвергнута вынужденному убою для выявления патологоанатомических изменений. У всех птиц отмечали перигепатит, перикардит (за исключением птицы № 3), увеличенное состояние селезенки. В толстом отделе кишечника - эрозии и петехии.

Патоморфологические изменения в органах и тканях взрослой индейки, убитой по окончании срока наблюдения, на макроуровне не фриксировали.

При проведении бактериологического исследования проводили микроскопию мазков-отпечатков из печени, селезенки, красного костного мозга и головного мозга. Во всех случаях выявляли грамотрицательные палочки.

Бактериологическое подтверждение сальмонеллёза проводили методом последовательного обогащения. Для этого исследования от 28 дневной птицы были отобраны печень, селезенка, головной мозг. От убитой взрослой птицы также были отобраны образцы аналогичного материала.

Во фрлакон с забуферной пептонной водой в стерильных условиях вносили кусочки внутренних органов павшей птицы из расчёта 1:10. Затем данные фрлаконы помещали на 18-часовое культивирование в термостат с температурным режимом $37^{0} \mathrm{C}$.

По истечению периода культивирования материал из фрлаконов был нами пересеян в бульон Раппопорта-Вассилиади в соотношении 0,1 $\mathrm{cm}^{3}$ исследуемого материала на 10 мл бульона. Культивирование проводили в течение 24 часов в термостате с температурным режимом $42^{\circ} \mathrm{C}$.

По истечению срока культивирования исследуемый материал был пересеян на следующие дифференциальные агаризированные питательные среды: среда Эндо, хромогенный агар для сальмонелл СМ1007. Культивирование посевов на среде СМ1007 проводилось в течение 24 часов, на среде Эндо в течение 48 часов в термостате с температурным режимом $37{ }^{\circ} \mathrm{C}$. Культивирование микроорганизмов на висмут-сульфитном агаре М027 в течение 24 часов термостате с температурным режимом $37^{\circ} \mathrm{C}$.

Результаты бактериологического исследования. Птица № 1, посев из печени. На хромагенной среде СМ1007 отмечается плотный рост колоний в размере 1-1,5 мм синего цвета. На среде Эндо - плотный рост колоний, имеющий специфический металлический блеск. На висмут сульфитном агаре рост чёрных колоний с металлическим блеском.

Птица № 1, посев из селезенки. На хромагенной среде СМ1007 отмечается плотный рост колоний в размере 1-1,5 мм синего цвета. На среде Эндо - рост колоний, имеющий специфический металлический блеск. На висмут сульфитном агаре рост чёрных колоний с металлическим блеском.

Птица № 1, посев из головного мозга. На хромагенной среде СМ1007 отмечается скудный рост колоний в размере 1-1,5 мм синего цвета. На среде Эндо - скудный рост колоний, имеющий специфический металлический блеск. На висмут сульфитном агаре рост чёрных колоний с металлическим блеском.

Птица № 4, посев из печени. На хромагенной среде СМ1007 отмечается рост колоний в размере 1-1,5 мм пурпурного цвета. На среде Эндо - рост колоний, имеющий специфический металлический блеск. На висмут сульфитном агаре рост чёрных колоний с металлическим блеском.

Птица № 4, посев из селезенки. На хромагенной среде СМ1007 отмечается рост колоний в размере 1-1,5 мм пурпурного цвета. На среде Эндо - рост колоний, имеющий специфический металлический блеск. На висмут сульфитном агаре рост чёрных колоний с металлическим блеском. 
Птица № 4, посев из головного мозга. На хромагенной среде СМ1007 отмечается скудный рост колоний в размере 1-1,5 мм пурпурного цвета. На среде Эндо - скудный рост колоний, имеющий специфический металлический блеск. На висмут сульфитном агаре рост чёрных колоний с металлическим блеском.

Полученные результаты позволяли предположить, что была обнаружена культура Escherichia coli. Тем не менее, были определены биохимические свойства данных изолятов бактерий.

Результаты окраски по Граму показали, что данная культура представляет собой грамотрицательные палочки. Поэтому для биохимической идентификации была выбрана тест-система для грамотрицательных энтеробактерий ЭНТЕРО тест $24 \mathrm{H}$.

Методика проведения биохимической идентификации, используя данную систему, заключается в следующем:

Таблица 3 - Результаты биохимической идентификации культур

\begin{tabular}{|c|c|c|c|c|c|c|c|c|c|}
\hline Тест & & 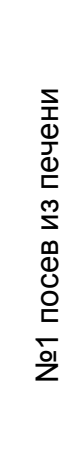 & 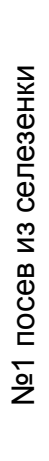 & 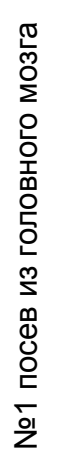 & 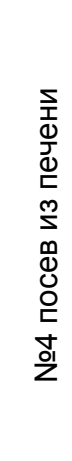 & 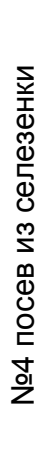 & 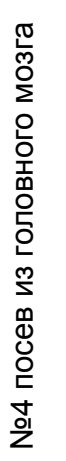 & 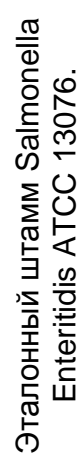 & 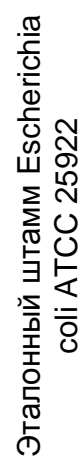 \\
\hline Уреаза & URE & - & - & - & - & - & - & - & - \\
\hline Аргинин & ARG & - & - & - & - & - & - & + & - \\
\hline Орнитин & ORN & + & + & + & + & + & + & + & + \\
\hline Лизин & LYS & + & + & + & + & + & + & + & + \\
\hline Сероводород & $\mathrm{H} 2 \mathrm{~S}$ & + & + & + & + & + & + & + & - \\
\hline Цитрат Симмонса & $\mathrm{SCl}$ & + & + & + & + & + & + & + & + \\
\hline Малонат & MAL & + & + & + & + & + & + & - & - \\
\hline ß - галактозидаза & ONP & + & + & + & + & + & + & - & + \\
\hline Салицин & SAL & - & - & - & - & - & - & - & - \\
\hline Сорбитол & SOR & + & + & + & + & + & + & + & + \\
\hline Мелибиоза & MLB & + & + & + & + & + & + & + & + \\
\hline Целлобиоза & CEL & - & - & - & - & - & - & - & - \\
\hline Лактоза & LAC & + & + & + & + & + & + & - & + \\
\hline Трегалоза & TRE & + & + & + & + & + & + & + & + \\
\hline Маннитол & MAN & + & + & + & + & + & + & + & + \\
\hline В - глюкуронидаза & GLR & + & + & + & - & - & - & - & + \\
\hline Дульцит & DUL & - & - & - & - & - & - & + & - \\
\hline Адонитол & ADO & - & - & - & - & - & - & - & - \\
\hline Арабитол & ART & - & - & - & - & - & - & - & - \\
\hline Сахароза & SUC & - & - & - & - & - & - & - & + \\
\hline Инозитол & INO & - & - & - & - & - & - & - & - \\
\hline Рафффиноза & RAF & - & - & - & - & - & - & - & + \\
\hline Эскулин & ESL & - & - & - & - & - & - & - & - \\
\hline ß - ксилоксидаза & $b X Y$ & - & - & - & - & - & - & - & - \\
\hline $\begin{array}{c}\text { Результат } \\
\text { идентификации. }\end{array}$ & & \multicolumn{3}{|c|}{$\begin{array}{c}\text { Salmonella enterica ssp. } \\
\text { arizonae } 61.38 \\
\text { Salmonella enterica ssp. } \\
\text { houtenae } 13.72 \\
\text { Salmonella enterica ssp. } \\
\text { Diarizonae } 4.1\end{array}$} & \multicolumn{3}{|c|}{$\begin{array}{c}\text { Salmonella enterica ssp. } \\
\text { arizonae } 46.10 \\
\text { Salmonella enterica ssp. } \\
\text { salamae } 30.63 \\
\text { Trabulsiella guamensis } \\
7.94\end{array}$} & & \\
\hline
\end{tabular}

Имеющиеся изоляты пересевали на скошенный агар МПА с последующим 24часовым культивированием при $37^{\circ} \mathrm{C}$ для получения суточной культуры. Затем 
готовили суспензию исследуемого микроорганизма в ффизиологическом растворе, доводя её до 1 степени мутности по Мак-Фарленду. С помощью автоматической пипетки-дозатора вносили взвесь культуры в 24 лунки в объёме $0,1 \mathrm{~cm}^{3}$. Затем в лунки H, G, F, E, D первого ряда вносили по 2 капли парафинового масла. Затем помещали данные стрипы в термостат для культивирования на 24 часа при $37{ }^{\circ} \mathrm{C}$.

После инкубации в лунку $1 \mathrm{H}$ добавляли 2 капли реактива Индол Ковача. В лунку 3Н вносили по одной капле реактива для ВПТ І и ВПТ ІІ. В лунку 2 Н вносили 1 каплю реактива для теста френилаланин.

Поскольку изначально известно, что заражающей культурой была сальмонелла подвида Arizonae, в качестве контроля использовали эталонные штаммы Salmonella Enteritidis ATCC 13076 и Escherichia coli ATCC 25922.

\section{ОБСУЖДЕНИЕ РЕЗУЛЬТАТОВ}

Полученные результаты идентификации бактерий подтверждают, что выделенные культуры являются сальмонеллами и относятся к подвиду Salmonella Arizonae. Тем не менее, данный подвид имеет яркие отличительные черты в отношении подвида Enterica. Наиболее наглядным среди данных свойств является то, что серовары подвида Arizonae достаточно часто являются лактозоположительными, что наглядно можно увидеть на питательных средах Эндо и Мак-Конки. Данная особенность обычно является признаком принадлежности к E. coli или иным колиформным бактериям. Помимо этого необходимо понимать, что возможность ферментировать лактозу у бактерий напрямую связана с активностью бетагалактозидазы. Помимо этого имеется другая отличительная черта сероваров подвида Arizonae - это бета-глюкуронидазная активность, которая проявляется окрашиванием в синий цвет колоний на хромогенных средах CM1007 аналогично культурам эшерихий.

Основным источником аризона-инфекции в промышленном индейководстве является инфицированное инкубационное яйцо. Распространению инфекции внутри предприятия способствует трансвариальный, фекально-оральный и алиментарный пути заражения. Установлены случаи контаминации сальмонеллой аризона на предприятии источником, которого послужила транспортная тара ${ }^{22}$.

При проведении лечебных мероприятий стоит осознавать, что антибиотикотерапия не всегда даёт необходимый результат, в связи, с чем с целью ликвидации заболевания рекомендуется уничтожить поголовье 232425.

Изученные штаммы бактерий рода Salmonella подвида Arizonae не являются вирулентными для белых мышей в достаточно больших концентрациях. Тем не менее, исследованные штаммы оказались способны вызвать сальмонелла-инфекцию в лабораторных условиях у индеек. Наиболее восприимчивой из подобранных возрастных групп оказалась птица в возрасте 28 дней. У данной птицы проявились типичные для сальмонеллёза клинические признаки. Более взрослая птица перенесла инфицирование в латентной фрорме.

\section{Выводы}

Экспериментальный аризоноз индеек сопровождается угнетением, малоподвижностью, полидипсией, анорексией, дрожью с развитием в дальнейшем одышки и диареи с зеленоватым оттенком и прожилками крови. Гибель наступает на 68 сутки, летальность - порядка $20 \%$.

Для идентификации сальмонелла аризона-инфекции в инкубационном яйце и продуктах индейководства необходимо учитывать особенности данного подвида сальмонелл - способность к сбраживанию лактозы, гидролизу желатина, бетаглюкуронидазная активность, не патогенность для белых мышей.

Идентификация Salmonella Arizonae после индикации культур с характерными свойствами и особенностями эффрективно осуществляется с применением тест- 
системы для грамотрицательных энтеробактерий ЭНТЕРО тест 24 Н. Основными диффреренциальными признаками сальмонелл подвида Arizonae являются бетагалактозидазная активность, бета-глюкуронидазная активность, положительная реакция малонатного теста.

\footnotetext{
${ }^{1}$ Канивец В.А. Индейководство России // Птицеводство. - 2009. - №11. - С.14

2 Timms R. Arizona infections in turkeys in Great Britain // Medical Laboratory Technology. - 1971. Apr;28(2): 150-6.

3 ДИРЕКТИВА COBЕТА 2009/158/EC от 30 ноября 2009 г. по ветеринарно-санитарным условиям, регламентирующим торговлю внутри Сообщества и импорт из третьих стран домашней птицы и инкубационных яиц

${ }^{4}[$ «О применении ветеринарно-санитарных мер в Таможенном союзе»

http://www.issa.ru/legislation/custdoc/custful_1523.html]

5 http://www.rg.ru/2014/06/09/ptica-site-anons.html

${ }^{6}$ New Salmonella outbreak linked to 179 illnesses. MeatPoultry.com,2011, November 22

${ }^{7}$ Salmonella enteritidis detection method gets interim NPIP approval. WorldPoultry.net, 2011, 14 March.

${ }^{8}$ US: five-state Salmonella outbreak linked to chicken livers. WorldPoultry.net, 2011, 10 November.

${ }^{9}$ Shire, Bernard. Countdown to test-and-hold."Meat\& Poultry", 2011, Vol. 57 No. 7 p. 40, 42, 46.

${ }^{10}$ Cargill recalls more ground turkey products. WorldPoultry.net, 2011,12 September.

${ }^{11}$ Thornton, Gary. Poultry Industry roundtable identifies 5 keys to food safety. "Poultry USA, 2011, Vol. 12 No. 6 p. $10,12,14-16$

${ }^{12}$ WHO study: half of Russian chicken a health hazard. WorldPoultry.net,2011, 22 September.

${ }^{13}$ Cox, N.A., et al. Zero Salmonella tolerance on poultry: worthy goal or trade protectionism? "Poultry International", 2011, Vol. 50 No. 12 p. 30-34.

${ }^{14}$ Gingerich, Eric. Efforts intensify to reduce Salmonella enteritidis infection in laying hens. "Egg Industry", 2011, Vol. 116 No. 5 p. 4,6 .

${ }^{15}$ On farm test to early detect Salmonella. WorldPoultry.net, 2011, 06 July.

${ }^{16}$ Gingerich, Eric. Efforts intensify to reduce Salmonella enteritidis infection in laying hens. "Egg Industry", 2011, Vol. 116 No. 5 p. $4,6$.

${ }^{17}$ Braun, Peggy G. Fate of Salmonella on egg shells. Труды Европейского симпозиума по качеству яиц и яйцепродуктов, Лейпциг, июль 2011 года.

${ }^{18}$ Roberts, JulietR.,KapilChousalkar. Eggqualityandfoodsafetyoftableeggs.Труды Европейского Симпозиума по качеству яиц и яйцепродуктов, Лейпциг, июль 2011 года.

${ }^{19}$ Kuhl, Henry, Carlos de Magalhaes. Benefits of proven continuous capacity egg washers. Труды Европейского Симпозиума по качеству яиц и яйцепродуктов, Лейпциг, июль 2011 года.

${ }^{20}$ US: five-state Salmonella outbreak linked to chicken livers. WorldPoultry.net, 2011, 10 November.

${ }^{21}$ http://www.garant.ru/products/ipo/prime/doc/4091056/

22 Hoover NJ, Kenney PB, Amick JD and Hypes WA, 1997. Preharvest sources of Salmonella colonization in turkey production.Poultry Science, 76, 1232-1238.

${ }^{23}$ Данилевская Н.В., Пименов Н.В. Проблема антибиотикорезистентности на примере лечения сальмонеллеза у домашних голубей./ Российский ветеринарный журнал. - М.: КолосС, 2005. - №4. - С. $21-24$

${ }^{24}$ Данилевская Н.В., Пименов Н.В. Новое в антибиотикотерапии: антибиотикорезистентность - угроза реальна./ Новейшие разработки в ветеринарии. Клеточная терапия: Мат-лы совм. конф. компании Нill's и РОНЦ им. Н.Н. Блохина, 21 апр. 2006. - М.: ГУ РОНЦ им. Н.Н. Блохина РАМН, 2006. - С. 16-22

25 Пименов Н.В., Данилевская Н.В. Антибиотикорезистентность сальмонелл, выделенных у домашних голубей. / Ветеринария. - 2006, №9. - С. 20-24
} 